\title{
THE BORREGO MOUNTAIN, CALIFORNIA, EARTHQUAKE OF 9 APRIL 1968: A PRELIMINARY REPORT ${ }^{1}$
}

By C. R. Alleen, A. Grantz, J. N. Brune, M. M. Clark, R. V. Sharp, T. G. Theodore, E. W. Wolfe, ANd M. WYss

The largest earthquake to hit California in more than 15 years occurred at 02:28:58.9 GCT on 9 April 1968 near Borrego Mountain, on the western edge of the Imperial Valley. The Seismological Laboratory at Pasadena has tentatively assigned the shock a magnitude of 6.5 , an epicentral location of $33^{\circ} 08.8^{\prime} \mathrm{N}, 116^{\circ}$ $07.5^{\prime} \mathrm{W}$, and a focal depth of $20 \mathrm{~km}$. The earthquake was felt throughout most of southern California and adjacent areas, but the absence of severe damage and casualties was in large part due to the relatively undeveloped nature of the epicentral region. Indeed, it would have been difficult to pick a location in the southernmost part of the State more remote from centers of population.

Although the earthquake occurred in the evening (6:29 p.m., local time), rapid computer location of the epicenter using the California Institute of Technology telemetered seismograph network allowed placement of the first portable seismograph unit within $3 \mathrm{~km}$ of the epicenter soon after midnight, and the fault trace was identified and the first displacement measurements made by 2:00 a.m. Detailed mapping of the fault trace by U. S. Geological Survey and Caltech personnel commenced the next day, which was fortunate in view of the fact that within four days much of the fault trace had already been obscured by blowing sand and dune buggy tracks. By April 12th, 14 portable seismograph units were in operation throughout the aftershock region.

The earthquake was accompanied by right-lateral displacement along a $33-\mathrm{km}$ segment of the Coyote Creek fault (Figure 1) - a major branch of the San Jacinto fault zone, which in turn is the most active member of the San Andreas fault system in southern California. Earthquakes of comparable magnitude had occurred earlier along the San Jacinto fault zone just to the north of this area in 1954 and just to the south in 1942, but no known major historic activity had occurred along the exact segment broken on April 9th. The Coyote Creek fault in this region has been mapped and its regional setting described by Dibblee (1954) and Sharp (1967).

The fault break consists of two northwest-trending en echelon segments that overlap and are separated by a $2 \mathrm{~km}$ wide zone of highly fractured terrane just southeast of the settlement of Ocotillo Wells. The maximum displacement observed was along the northern segment, $5 \mathrm{~km}$ northwest of Ocotillo Wells, where $38 \mathrm{~cm}$ of right-lateral slip was indicated by offset channels and vehicle tracks and by displaced slabs of dried mud crust. The maximum horizontal slip observed along the southern segment, $20 \mathrm{~cm}$, was noted $10 \mathrm{~km}$ southeast of Ocotillo Wells. Vertical displacements were nil in most areas where the fault cut level ground, but wherever the break lay along a pre-existing fault scarp or bordered hills, vertical displace-

${ }^{1}$ A joint contribution of the California Institute of Technology, Division of Geological Sciences (Contribution No. 1532) and the National Center for Earthquake Research, U.S. Geological Survey. 
ments of up to $20 \mathrm{~cm}$ occurred - almost invariably with the same sense of displacement as that of the earlier movements that produced the fault scarps and hills. Neither side was consistently uplifted with respect to the other.

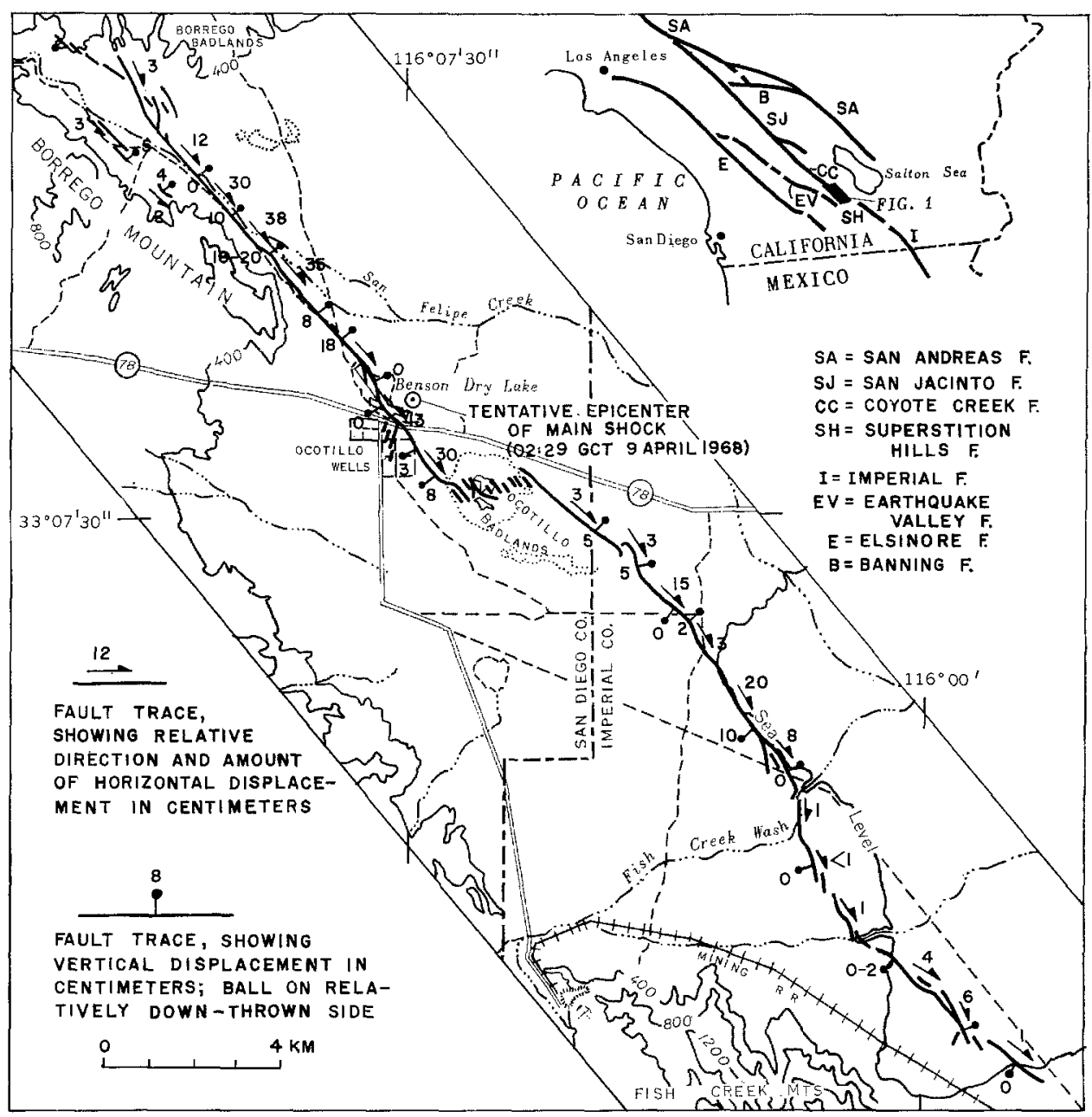

Fig. 1. The Borrego Mountain area, southern California, showing the tentative epicenter earthquake of 9 April 1968, and the displacements that accompanied the earthquake along 33 $\mathrm{km}$ of the Coyote Creek fault trace.

In most areas, the fault trace comprised a series of overlapping en echelon cracks. The total width of the fractured zone along the main fault trace varied from less than 1 meter to several hundred meters, but in the wider parts of this zone most of the displacement took place in a narrower zone of fractures that ranged in width from less than 1 to 15 or 20 meters. Had the zone of surface faulting traversed a built-up area, most of the damage from fault displacement would have occurred within this narrower zone-a zone which varied in position from the center to either side of the entire fracture zone. The trace was entirely within Quaternary alluvium 
and lake beds, except at the northernmost extremity where branches cut steeply dipping beds of the Pliocene and Pleistocene Palm Spring Formation, and in the Ocotillo badlands where the Borrego Formation and Ocotillo Conglomerate (both Quaternary) were displaced (Downs and Woodard, 1962; Theodore Downs and J. A. White, oral communication, 1968). In every area where a pre-existing fault was indicated by a scarp or ground-water barrier, the rupture took place almost exactly along the line of earlier breaks. Theodolite surveys across the fault at Highway 78 near Ocotillo Wells, repeated nine times between April 9th and April 27th, have as yet given no indication of post-earthquake creep, such as was so obvious following the Parkfield-Cholame earthquakes of 1966 (Brown and others, 1967; Smith and Wyss, in press).

A single foreshock of magnitude 3.7 preceded the main shock by about a minute, but a Caltech micro-earthquake trailer operating at Obsidian Butte, $50 \mathrm{~km}$ east of the epicenter, recorded no other precursory activity; indeed, the seismograph trace was remarkably quiet in the hours preceding the shock, and the general level of activity at this station had been very low during the preceding 4 months. Preliminary aftershock locations, based on four permanent stations within $80 \mathrm{~km}$ and utilizing some data from temporary stations within the epicentral area, indicate a zone of activity extending along the projected fault trace from about $33^{\circ} 18^{\prime} \mathrm{N}$, $116^{\circ} 19^{\prime} \mathrm{W}$ to $32^{\circ} 59^{\prime} \mathrm{N}, 115^{\circ} 57^{\prime} \mathrm{W}$-a total length of about $50 \mathrm{~km}$. Unlike many other large earthquakes, the epicenter of the main shock lay midway along the fault trace and the zone of aftershock activity.

In addition to the primary displacement of the Coyote Creek fault, minor horizontal displacements or creep episodes must have taken place at about the same time on the Superstition Hills fault, Imperial fault, and Banning-Mission Creek (San Andreas) fault $-45 \mathrm{~km}, 70 \mathrm{~km}$, and $50 \mathrm{~km}$, respectively, from the epicenter. Although these fresh breaks were not noticed until a few days after April 9th, no other significant earthquakes have been identified in these areas, and the remarkable freshness of the surficial cracks makes it highly likely that the displacements or creep episodes were triggered by the Borrego Mountain earthquake. In any case, the fresh cracks must postdate the last major rainfall in this region on March 8th. Theodolite resurveys of several small nets that had been established across these faults 3-11 months prior to the earthquake indicate the following cumulative rightlateral displacements as of April 28th: $1.2 \mathrm{~cm}$ at the Imperial fault where it crosses Highway $80,1.1 \mathrm{~cm}$ where the fault crosses Worthington Road, $6 \mathrm{~km}$ northwest, $1.3 \mathrm{~cm}$ at Harris Road, $11 \mathrm{~km}$ northwest; $2.2 \mathrm{~cm}$ where the Superstition Hills fault crosses Imler Road; and $0.9 \mathrm{~cm}$ on the Banning-Mission Creek fault at a point east of Thermal. Fresh breaks along the Imperial fault extend for more than 20 $\mathrm{km}$, distinctly farther both to the north and south than the 10-km segment broken during the magnitude 3.6 shock of 1966 (Brune and Allen, 1967). Fresh breaks along the Superstition Hills fault extend at least $8 \mathrm{~km}$ north from Imler Road, and new cracks along the Banning-Mission Creek fault have been observed at several points along the $30-\mathrm{km}$ segment from Salton Creek northwest into the Meca Hills. In all three areas the fresh cracks clearly indicate right-lateral displacement of $1-2 \mathrm{~cm}$. Although most of the displacements took place prior to the first remeasurements following the April 9th event, surveys that have been repeated an average of 4 
times at each locality between April 9th and April 28th suggest that minor horizontal creep may be continuing at some places. These observations of displacements or creep episodes on nearby faults that probably were triggered by the Borrego Mountain earthquake are the most surprising, and perhaps the most significant, result of the investigation thus far.

\section{ACKNOWLEDGMENT}

Participation in this study by the California Institute of Technology was supported by National Science Foundation Grant GA-1087.

\section{REFERENCES}

Brown, R. D., Jr., J. G. Vedder, R. E. Wallace, E. F. Roth, R. F. Yerkes, R. O. Castle, A. O. Waananen, R. W. Page, and J. P. Eaton, 1967, The Parkfield-Cholame, California, earthquakes of June-August 1966-Surface geologic effects, water-resources aspects, and preliminary seismic data: U.S. Geol. Survey Prof. Paper 579, pp. 66.

Brune, J. N. and C. R. Allen (1967). A low-stress-drop, low-magnitude earthquake with surface faulting: The Imperial, California, earthquake of March 4, 1966: Bull. Seism. Soc. Am. 57, 501-514.

Dibblee, T. W., Jr. (1954). Geology of the Imperial Valley region, California, [Pt.] 2 in Chap. 2 of Jahns, R. H., ed., Geology of southern California: California Div. Mines Bull. 170, 2128.

Downs, Theodore and G. D. Woodard (1962). Middle Pleistocene extension of the Gulf of California into the Imperial Valley [abs.]: Geol. Soc. Am. Spec. Paper 68, 21.

Sharp, R. V. (1967). San Jacinto fault zone in the Peninsular Ranges of southern California: Bull. Geol. Soc. Am., 78, 705-730.

Smith, S. W. and M. Wyss (1968). Displacement on the San Andreas fault initiated by the 1966 Parkfield earthquake: Bull. Seism. Soc. Am. in press.

Shismological Laboratory

California Institute of Technology

Pasadena, California

(C.R.A., J.N.B., AND M.W.)

U.S. Geological Survey

Menlo Park, California

(A.G., M.M.C., R.V.S., T.G.T., And E.W.W.)

Manuscript received April 29, 1968 